\title{
Controls on phytoplankton productivity in a wet-dry tropical estuary
}

Burford, M.A. ${ }^{1}$, Webster, I.T. ${ }^{2}$, Revill, A.T. ${ }^{3}$, Kenyon, R.A. ${ }^{4}$, Whittle, M. ${ }^{5}$, Curwen, G. ${ }^{1}$

${ }^{1}$ Australian Rivers Institute, Griffith University, Nathan, QLD 4111, Australia

${ }^{2}$ CSIRO Land \& Water, GPO Box 1666, Canberra, ACT 2601, Australia

${ }^{3}$ CSIRO Marine \& Atmospheric Research, GPO Box 1538, Hobart, TAS 7001, Australia

${ }^{4}$ CSIRO Marine \& Atmospheric Research, PO Box 2583, Brisbane, QLD 4001, Australia

${ }^{5}$ Aquenal, 244 Summerleas Rd, Kingston TAS 7050, Australia

${ }^{1}$ Corresponding author: m.burford@griffith.edu.au,

Phone: +61 73735 6723, Fax: +61 737357615

Keywords: nutrients, primary productivity, tropics, turbidity, microalgae 


\begin{abstract}
Flood events typically enhance primary productivity in estuaries via the increased nutrient inputs from land runoff. This study examined the drivers of phytoplankton biomass accumulation and productivity in a tropical estuary with a distinct wet-dry seasonality, i.e. months of little or no rainfall, and a highly episodic extended wet season. The study found that over two wet seasons, there was little evidence of freshwater inputs increasing nutrient concentrations, and chlorophyll $a$ concentrations and phytoplankton productivity rates decreased in the water column, probably due to low water residence times. The magnitude and duration of freshwater flows in the wet season appeared to affect the scale of reduction of phytoplankton productivity and biomass accumulation. In contrast to many studies, there was also no evidence of post-flooding stimulation of chlorophyll $a$ concentration with net export of nutrients in both the wet and dry seasons. Nitrogen $(\mathrm{N})$ and light appeared to be key limiting factors for phytoplankton growth with estuarine DIN rapidly turned over by phytoplankton, no evidence of $\mathrm{N}$ fixation by phytoplankton, and a response to $\mathrm{N}$, but not phosphorus $(\mathrm{P})$, in algal bioassays. Tidal resuspension of sediments was an important physical process that limited light availability for primary productivity. The lack of higher nutrient concentrations as a result of freshwater inputs, and lack of post-flood algal growth stimulation contrasts with the findings of studies in eutrophied systems.
\end{abstract}

\title{
Introduction
}

Phytoplankton productivity in estuaries is controlled by both nutrient availability and the physical properties, including the scale of tidal exchange, geomorphological characteristics of the estuary, and the magnitude, timing and duration of freshwater flow events. Flow events can have major impacts on biogeochemical processes and primary productivity. This is most pronounced in the subtropics and tropics where the magnitude and duration of flow events are much higher, due to monsoonal weather patterns. Freshwater flow can play an important role in increasing nutrient concentrations and loads to estuaries (Eyre, 2000; Eyre and Ferguson, 2006; Webster et al., 2005). Additionally, flow events change water residence times which can have negative effects on phytoplankton productivity. Nutrient inputs during flooding can, 
in turn, fuel primary production in the months during and post-flooding once flow and turbidity have decreased, and salinity has increased (Mallin et al., 1993; Gillanders and Kingsford, 2002; Murrell et al., 2007).

Wet and dry tropical/subtropical river systems account for $68 \%$ of Australian estuaries, meaning that they are an important contributor to the productivity of estuarine and coastal systems (Bucher and Saenger, 1994). Indeed studies have shown a correlation between catches of estuarine fish and crustaceans, and measures of freshwater flow which suggests that freshwater inputs may be providing nutrients and carbon to fuel productivity in estuaries (Gillanders and Kingsford, 2002; Robins et al., 2005). Conversely, estuarine productivity appears to be negatively affected if the upstream river is regulated, reducing the magnitude of high flow events (Kenyon et al., 2004; Burford et al., 2011).

Eyre (2000) has proposed that estuaries of the wet and dry tropics/subtropics have four regime states throughout a typical year. During floods, freshwater flushes nutrients and sediments out to sea. This is followed by a recovery phase where turbidity begins to decrease, however low light availability prevents phytoplankton growth. In the medium flow phase, increasing light and nutrient availability stimulates phytoplankton biomass. Finally, in the dry season, phytoplankton become nutrient limited again, with a resulting decrease in biomass.

This study therefore examined the role of freshwater nutrient inputs in stimulating phytoplankton productivity in an estuary in the dry tropics. Nutrient loads imported and exported from the estuary were compared with phytoplankton biomass, productivity over the wet and dry seasons. Using this information this study determined whether an estuary in the dry tropics had characteristics consistent with the proposed regime states of Eyre (2000).

\section{Methods}

Study site

The Norman River estuary $\left(140.82{ }^{\circ} \mathrm{E}, 17.463{ }^{\circ} \mathrm{S}\right)$ is a tide-dominated estuary situated in the southeast Gulf of Carpentaria, Australia (Fig. 1) and is classified amongst those tropical estuaries that have a low rainfall and tidal range (Bucher and Saenger, 1994). A total of 81 
estuaries across northern Australia, including many in the southern Gulf of Carpentaria, fall within this category.

The estuary is approximately $80 \mathrm{~km}$ long, limited at its up-estuary end by an overflow weir at Normanton (Glenore Weir). Tides in the estuary are dominantly diurnal with a 3-4 m range near the mouth during spring tides decreasing to a range of less than $1 \mathrm{~m}$ during neap tides. A model of tide heights predicts that tidal ranges at Glenore Weir would be about half of those at the mouth (I. Webster, unpubl. data). In keeping with many of the estuaries in this area, it has a relatively simple morphology, with a main river channel fringed by intertidal mudflats, above which is a narrow strip of mangrove forest (total mangrove area is $55.24 \mathrm{~km}^{2}$, Avicennia-dominated) (National Land \& Water Resources Audit (NLWRA) 2001, www.nlwra.gov.au). The channel area is $36 \mathrm{~km}^{2}$ and beyond the mangroves are extensive saltflats $\left(356 \mathrm{~km}^{2}\right)$.

The catchment is $49,600 \mathrm{~km}^{2}$ in area, much of which is low-lying flat country with little vertical relief. The soils are characterized as having low to modest fertility (B. Powell, pers. comm.). The vegetation is dominated by eucalypts and grassland with low intensity cattle grazing. There is limited information on land use in the catchment and it has been described as principally woodland (http://adl.brs.gov.au/water2010/pdf/catchment_1009_0_summary.pdf).

The Norman River (420 km long) is a tropical dryland river with a mean annual rainfall of $913 \mathrm{~mm}$ (at Normanton). Almost all the rainfall occurs in the austral summer wet season (December to March). The southern Gulf rivers typically have summer flows that are highly intermittent (Kennard et al. 2010). The Norman River has a mean annual discharge of 2,346,000 ML based on a gauging station above Glenore Weir above the estuary (Fig. 2, www.derm.qld.gov.au/water). In the dry season the river is a series of disconnected waterholes again, typical of the southern Gulf rivers. There is little or no freshwater flow from the river to the estuary at this time of year. In the wet season, the dramatic increase in flow can result in extensive flooding of the catchment and coastal areas.

\section{Sampling protocol}

The experimental design consisted of regular sampling for water quality at four sites throughout the estuary for two six month periods (November 2008 - March 2009, 
November 2009 - March 2010) which captured late dry and wet seasons, as well as two mid-dry season sampling events in both June 2009 and June 2010 (Fig. 1). Additionally, there were three intensive field trips (January 2009, November 2009, and February 2010) to measure primary productivity, phytoplankton $\mathrm{N}$ uptake, phytoplankton response to nutrient addition, and a range of other physical and chemical parameters.

For the regular sampling, the four sites were sampled fortnightly (CQ2, CQ3, WQ1, RQ1) at low tide for water quality parameters: one of the sites at the Karumba township was also sampled at high tide (CQ1, Fig. 6.4). During the sampling occasions, low tides were typically in the morning. In the second year, an additional site was sampled monthly at the wharf in the township of Normanton (NW, $80 \mathrm{~km}$ upstream of Karumba). To determine the variability in water quality longitudinally samples were taken every $10 \mathrm{~km}$ along the length of the estuary. Transects were done from CQ1 upstream to the township of Normanton (90 $\mathrm{km}$ upstream) on the outgoing tide on four occasions, two in the wet season (January 2009, February 2010), and two in the dry season (early and late November 2009, river only accessible to $70 \mathrm{~km}$ upstream). Duplicate samples were taken for total N (TN), total P (TP) and on two occasions, chlorophyll $a$ concentrations. Samples were processed using the same methods as for the regular sampling.

The following parameters were measured monthly: TN, TP, $\mathrm{NH}_{4}$, nitrate/nitrite $\left(\mathrm{NO}_{2}+\right.$ $\mathrm{NO}_{3}$ ), and FRP concentrations. Dissolved organic $\mathrm{N}(\mathrm{DON})$ and $\mathrm{P}(\mathrm{DOP})$ concentrations were determined on a subset of samples by measuring TDN and TDP, and subtracting the inorganic nutrient concentrations. The following parameters were measured fortnightly: chlorophyll $a$ and total suspended solids concentrations (TSS), $\delta^{15} \mathrm{~N}$ stable isotope ratios of suspended particulate matter, physico-chemical parameters (temperature, salinity, oxygen, $\mathrm{pH})$ and secchi disc readings.

For nutrients, chlorophyll and suspended solids, replicate water samples were taken at the surface and $1 \mathrm{~m}$ from the bottom in the middle of the river or creek, with a van Dorn sampler. Subsamples were taken for TN and TP and placed on ice until frozen in the laboratory. For dissolved nutrients, samples were immediately filtered through $0.45 \mu \mathrm{m}$ membrane filters then placed on ice until frozen in the laboratory. Water subsamples for chlorophyll and TSS/stable isotope analyses were kept on ice until filtered onto pre- 
weighed and pre-combusted glass fibre filters (Whatman GF/F or Avantec GF75) then frozen until analyzed.

For physico-chemical parameters, a calibrated multi-sensor logger (Sonde) was used and measurements of temperature, salinity, oxygen, and $\mathrm{pH}$ were taken at $1 \mathrm{~m}$ intervals through the water column from surface to bottom at each site. Secchi disc readings were also done at each site.

\section{${ }^{13} \mathrm{C}$-bicarbonate and ${ }^{15} \mathrm{~N}$-nitrogen uptake experiments}

In January 2009, November 2009, February 2010, incubation experiments were undertaken to determine ${ }^{13} \mathrm{C}$ - bicarbonate uptake as a measure of primary productivity (three sites), and ${ }^{15} \mathrm{~N}$-nitrogen uptake (one site) as a measure of $\mathrm{NH}_{4}, \mathrm{NO}_{3}$ and urea uptake by phytoplankton. The protocol of Burford et al. (2011) was used. For the ${ }^{13} \mathrm{C}$ uptake experiments, surface water samples were used to fill triplicate bottles which were incubated at one of six light levels: $0,5,14,25,50$ and $100 \%$ of surface light. ${ }^{13} \mathrm{C}$-sodium bicarbonate $\left({ }^{13} \mathrm{C} 99 \%\right.$, Cambridge Isotope Laboratories, Andover, Massachusetts) was added to bottles at an enrichment level of $\sim 10 \%$ of background bicarbonate. Samples were incubated in full sunlight either side of local solar noon for 2 to $3 \mathrm{~h}$ and ambient water temperature was maintained. For the ${ }^{15} \mathrm{~N}$-uptake experiments the same protocol was followed but ${ }^{15} \mathrm{~N}-\mathrm{NH}_{4}, \mathrm{NO}_{3}$ and urea $\left({ }^{15} \mathrm{C} 99 \%\right.$, Cambridge Isotope Laboratories, Andover, Massachusetts) was added at 10\% enrichment (Glibert et al., 1991). Samples were only incubated in full sun for $1 \mathrm{~h}$. For both ${ }^{15} \mathrm{~N}$ and ${ }^{13} \mathrm{C}$ uptake experiments, known volumes of water from the bottles were filtered onto precombusted glass fibre (Whatman GF/F) filters and frozen until returned to the laboratory. Filters were then dried at $60^{\circ} \mathrm{C}$ for $24 \mathrm{~h}$ before being analyzed for ${ }^{13} \mathrm{C} /{ }^{12} \mathrm{C}$ and ${ }^{15} \mathrm{~N} /{ }^{14} \mathrm{~N}$ isotope ratio on a mass spectrometer (GV Isoprime, Manchester, UK).

At times when the salinity was lower than seawater, a water sample was also collected at each site for alkalinity measurements. Water samples were kept in filled bottles on ice until analyzed in the laboratory by titration (American Public Health Association, 2005). Alkalinity, $\mathrm{pH}$, water temperature and conductivity values were used to determine the bicarbonate concentrations in the water. Water samples were also collected for urea, $\mathrm{NH}_{4}$ and $\mathrm{NO}_{2}+\mathrm{NO}_{3}$ analyses using methods outlined above. Light 
intensity profiles were taken at each site using a 4 pi sensor (Licor). Secchi depth readings were converted to euphotic depth values using a multiplier of 1.7 (Chapra, 1997). Water column areal productivity $\left(\mathrm{mg} \mathrm{C} \mathrm{m}^{-2} \mathrm{~d}^{-1}\right)$ was calculated by integrating

primary productivity through the water column based on the ${ }^{13} \mathrm{C}$-bicarbonate incubation data, alkalinity measurements and light profiles.

The method of Cole and Cloern (1987) was used to regress the composite variable B x $\mathrm{Z} \times \mathrm{I}$, the product of chlorophyll $a$ concentrations, euphotic depth and surface irradiance with primary productivity at each site and sampling occasion.

$\mathrm{N}$ uptake rate calculations were based on the method of Dugdale and Goering (1967). However, the poor correlation between chlorophyll and particulate $\mathrm{N}(\mathrm{PN})$ at the time of the incubations $\left(\mathrm{R}^{2}=0.15\right)$ suggested that much of the PN was not living phytoplankton. Therefore chlorophyll concentrations were used to estimate PN concentrations using a ratio of 7.6:1 atomic PN:chlorophyll $a$ (Strickland, 1965; Redfield, 1958) in order to calculate biomass-specific uptake rates.

\section{Algal bioassays}

In January 2009, November 2009 and February 2010, phytoplankton bioassays were undertaken to determine the response of phytoplankton to the addition of nutrients. The response was measured as photosynthetic yield response (Ganf and Rea, 2007; Burford et al., 2011). Surface water samples were collected at the four sites on the first field trip, and three sites on subsequent trips. The bioassays involved four treatments: control, N, P and N+P addition. There were three replicate bottles of each treatment at each site. Ammonium chloride was added as the $\mathrm{N}$ treatment; potassium dihydrogen phosphate was added as the $\mathrm{P}$ treatment. The ambient DIN concentration was assumed to be $7 \mu \mathrm{mol} \mathrm{L}{ }^{-1}$ and the ambient FRP concentration was assumed to be $0.32 \mu \mathrm{mol} \mathrm{L}{ }^{-1}$, and nutrients were added at ten times ambient concentrations. Bottles were incubated in plastic bins with flow-through river water under ambient light conditions for $24 \mathrm{~h}$. Bottles were then stored in the dark for at least $20 \mathrm{~min}$ prior to reading the photosynthetic yield response using a PHYTOPAM (Heinz Walz GmbH, Effeltrich, Germany). Two readings were taken from each bottle. 


\section{Current measurements}

Current velocities were measured during the $2008 / 2009$ wet season $\left(20^{\text {th }}\right.$ January $-20^{\text {th }}$

February) and again during the intensive field campaign in November 2009. Measurements were made with $1 \mathrm{kHz}$ Aquadopp Acoustic Doppler current meter (ADCP; Nortek AS, Norway). In each case the ADCP was deployed within the top $1 \mathrm{~m}$. In the wet season this was via attachment to a floating pontoon in approximately $4 \mathrm{~m}$ of water. It was expected that during this period flow would remain in one direction so for logistics reasons the ADCP was orientated along the line of flow facing down through the water column. During the dry season the ADCP was deployed by attachment to a moored boat for $5 \mathrm{~d}$. In this instance it was anticipated that flow direction would vary across the tide thus the ADCP was deployed vertically to allow the internal compass to determine the direction as well as speed of flow. At the same time a datalogger (Hydrolab DS5) was deployed adjacent to the ADCP to measure turbidity at $1 \mathrm{~h}$ time intervals over the tidal cycle.

\section{Analyses}

Water samples for TN and TP were analyzed using a persulfate digestion process and standard colorimetric methods (American Public Health Association, 1995). Water samples for $\mathrm{NH}_{4}, \mathrm{NO}_{2}+\mathrm{NO}_{3}$ and FRP were analyzed using standard colorimetric methods (American Public Health Association, 1995). For urea, samples were analyzed using the diacetyl monoxime method (Rahmatullah and Boyde, 1980).

For TSS, glass fibre filters were dried at $60^{\circ} \mathrm{C}$, and reweighed. These filters were retained for stable isotope analysis of $\delta^{15} \mathrm{~N}$ on a mass spectrometer (GV Isoprime, Manchester UK). For chlorophyll $a$ concentrations, samples were extracted by sonicating filters for $1 \mathrm{~min}$ in cold $100 \%$ acetone, and measured either spectrophotometrically or spectrofluorometrically (Jeffrey and Welshmeyer, 1997).

Statistical analyses were conducted using SAS software. Due to the non-parametric nature of the water quality data, a Spearman's Rank Correlation analysis was performed. A posthoc Bonferroni test was also performed to reduce the level of statistical significance. Data from the four sites for wet and dry season was combined, and dry season was also analyzed alone. An ANOVA analysis with a posthoc Bonferroni test was performed on photosynthetic yield measurements in the algal bioassays, after testing for normality. 


\section{$N$ and $P$ budgets}

Mathematical models were developed to calculate the loads of $\mathrm{N}$ and $\mathrm{P}$ in and out of the Norman River estuary. During the dry season, when river flow was zero, transport of the dissolved nutrient phase was dominated by mixing processes due to the back and forth motion of the tides. Such mixing transport along estuaries is often described as turbulent diffusion in which the flux, $F$, is represented as:

$$
F=-A D \frac{\partial C}{\partial x}(1)
$$

where $D$ is the turbulent diffusion coefficient determined at a particular location along the estuary $x, A$ is cross-sectional area, and $\partial C / \partial x$ is the long-estuary concentration gradient of the dissolved substance. Thus, if dissolved nutrient concentrations within the estuary are greater than those in the sea, transport will be towards the sea. The gradient can be estimated from separated concentration measurements, say $C_{1}$ and $C_{2}$ at distances $x_{1}$ and $x_{2}$ as:

$$
\frac{\partial C}{\partial x} \sim \frac{C_{1}-C_{2}}{x_{1}-x_{2}}
$$

Instead of using measurements separated spatially, measurements on different phases of the tidal cycle were used as these effectively represent spatially separated parcels of water at any given time. Dissolved inorganic nutrient concentrations measured around high and low tide at the sites at the Karumba township (CQ1, CQ2) were used for the calculations. A one-dimensional hydrodynamic model for the estuary was used to simulate long-channel velocities and water levels along the estuary as these respond to tidal forcing at Karumba. It is similar to a model developed for the Coorong in southern Australia (Webster, 2010). The Norman River estuary model allowed the estimations of the longitudinal positions of high and low tide samples as they would be at mid-tide.

Two calibration coefficients were determined by matching ADCP measurements at Karumba (see above) and measured water levels at Glenore Weir (www.derm.qld.gov.au) with the corresponding simulations. Bottom friction was 
assumed to be quadratic in the flow speed. The first calibration coefficient was a friction coefficient assumed uniform along the estuary. In the absence of bathymetric charts along most of the estuary, water depths were assumed to vary linearly with distance between Karumba and Glenore Weir. Cross-sections near Karumba enabled water depth to be estimated at that end of the estuary. The second calibration coefficient was the water depth at the Glenore Weir.

A second one-dimensional model was developed to simulate horizontal solute transport (Webster et al., 2005). This model averaged over the tides and solved the advection-diffusion equation. Measured longitudinal profiles of salinity were used to estimate the long-channel diffusion coefficients required to determine long-estuary nutrient fluxes using Equation 1. Rates of net loss/gain of these nutrients within the estuary were also calculated from the change in estimated total mass of DIN and FRP between the times of the two longitudinal surveys in November 2009 (dry season).

The result was calculated estimations of the fluxes of DIN and FRP past Karumba (near the estuary mouth) for the sampling times excluding those obtained during times when the Norman River was flowing. Error bars were derived from the variation in sample concentration across two replicates at two depths obtained at each sampling location. It is acknowledged that there will be errors associated with the estimated position of the sample at mid-tide, although this is likely to be small compared with the assumption that the instantaneous concentration distribution is a smooth function of longitudinal distance.

In this study, the majority of particulate nutrients were associated with the sediments. Since sediments are actively suspended and settle over the tidal cycle, the approach outlined above cannot be used. Nevertheless, the instantaneous flux of suspended sediment across a particular cross section of the estuary can be estimated as:

$$
F=Q C
$$

Where: $C=$ concentration, $Q=$ flow volume

The ADCP and turbidity data outlined above was used to estimate a time series of suspended sediment concentration and flow volume past Karumba using an assumed 
channel width and a cross-sectional area which changed with tidal stage. Channel width was measured from a Google Earth $\subset$ image of the estuary. Although it is not known at what tidal stage the image was obtained it appears that the flow was confined to the channel at the time. With typical bank slopes of $30 \%$ in such estuaries and with a tidal range of the order of $2 \mathrm{~m}$ during spring tides, the estimated uncertainty in the mean channel width over the tidal cycle is likely to be less than $5 \mathrm{~m}$.

For the Norman Estuary it was assumed that TSS can be calculated from turbidity data using the following equation from the Fitzroy estuary (Webster and Ford, 2010):

$$
\mathrm{TSS}=1.13( \pm 0.02 \mathrm{SE}) \mathrm{x} \text { turbidity }
$$

where the units of TSS are taken to be $\mathrm{gm}^{-3}$ and turbidity is expressed in NTU. In both the Fitzroy and Norman River estuaries the suspended material is fine sediment that derives from erosion in a lowland catchment. The relative error on the predicted relationship is greatest for turbidity less than $\sim 2$ NTU where the scatter in TSS is $\pm 1 \mathrm{mg} \mathrm{L}^{-1}$. Surface TSS and turbidity were correlated $\left(\mathrm{R}^{2}=0.85\right)$ at $\mathrm{CQ} 2$ in the intensive field trip in November 2009 using methods for sampling and processing TSS (outlined above) and measures of turbidity using a datalogger (Sonde).

The linear regressions between PN, PP, and TSS were determined for the three sampling sites, CQ1, CQ2 and CQ3:

$$
\begin{aligned}
& \mathrm{PN}=0.00110( \pm 0.00004 \mathrm{SE}) \times \mathrm{TSS} \\
& \mathrm{PP}=0.00021( \pm 0.00001 \mathrm{SE}) \times \mathrm{TSS}
\end{aligned}
$$

Using the relationships between PN, PP and TSS concentration (Equations 5, 6), and the relationship between TSS and turbidity (Equation 4), the instantaneous flux of particulate nutrients can be calculated using Equation 3.

The DIN demand by phytoplankton across the whole estuary during the dry season was estimated. Chlorophyll-specific $\mathrm{NH}_{4}$ and $\mathrm{NO}_{3}$ uptake rates for site $\mathrm{CQ} 2$ were assumed to represent the whole estuary, and this was multiplied by the minimum and maximum chlorophyll concentrations determined for the 14 sampling sites on the two transects down the estuary in early and late November 2009 to determine range of absolute uptake rates. Uptake was assumed to occur through the water column (3 m 
mean depth) because the water column was well mixed. The estuary water volume was calculated to be $1.23 \times 10^{8} \mathrm{~m}^{3}$ at mid tide, based on measured estuary widths (from Google Earth $($ ) and from water depth along the estuary at the average simulated tidal elevation at cross-sections along the estuary.

\section{Results}

Water quality - regular sampling

In the two years of the study, the peak in freshwater flow during the 2008/2009 wet season was classified as a major flood based on the gauging height, and in the 2009/2010 wet season as moderate (Fig. 2, www.bom.gov.au). Mean salinity across the sampling sites decreased from hypersaline to close to zero in early January 2009 and remained at these values until March 2009 when salinity began to increase (Fig. 3). In the second six-month period, salinity again dropped in early January 2010 but was more variable, only decreasing to zero for short periods, i.e. late January.

The mean morning water temperature, measured fortnightly across all sites, was similar $\left(28.9-29.5^{\circ} \mathrm{C}\right)$ and there was little temporal variation over the two six-month periods (Table 1). $\mathrm{pH}$ ranged from 7.46 to 7.86 , and DO ranged from 5.32 to $5.40 \mathrm{mg}$ $\mathrm{L}^{-1}$ in the lower estuary, and was higher $\left(6.69 \mathrm{mg} \mathrm{L}^{-1}\right)$ in the upper estuary (based on data from the second year). Secchi disc readings ranged between 0.17 and $0.40 \mathrm{~m}$.

TN and TP ranged from 31 to 40 , and 1.5 to $3.4 \mu \mathrm{mol} \mathrm{L} \mathrm{L}^{-1}$, respectively, with no obvious increase over the wet season. $\mathrm{NH}_{4}, \mathrm{NO}_{2}+\mathrm{NO}_{3}$ and FRP concentrations were typically above detection limits $\left(0.14\right.$ and $0.06 \mu \mathrm{mol} \mathrm{L} \mathrm{L}^{-1}$ for $\mathrm{N}$ and $\mathrm{P}$ respectively) and highly variable within sites. $\mathrm{NH}_{4}$ and FRP concentrations peaked at the commencement of the wet season when salinity dropped, but $\mathrm{NO}_{2}+\mathrm{NO}_{3}$ did not (Fig. 3 ). In the case of FRP, this was mostly the result of a much higher concentration being discharged from Russell Creek $\left(2.48 \mu \mathrm{mol} \mathrm{L}^{-1}\right)$ compared the Norman River and Walker Creek $\left(0.35 \pm 0.11 \mu \mathrm{mol} \mathrm{L}{ }^{-1}\right)$. This creek received overland flow from the adjacent Bynoe River. FRP constituted 8 and $11 \%$ of the TP, and DIN $\left(\mathrm{NH}_{4}+\mathrm{NO}_{2}+\mathrm{NO}_{3}\right)$ constituted 9 and $5 \%$ of the TN. Based on two sampling occasions during the wet and dry seasons, most of the TN was in the form of DON (65 and 62\% in the dry and wet seasons respectively) and most of the TP was present as particulate 
$\mathrm{P}$ (PP, 73 and $72 \%$ in the dry and wet seasons respectively). The molar TN:TP ratio was 14.3 to 17.9 in the lower estuary, and 30.2 in the upper estuary. TSS concentrations ranged from 144.2 to $430 \mathrm{mg} \mathrm{L}^{-1}$, and were highly variable within sites (Table 1). Mean $\delta^{15} \mathrm{~N}$ values in the POM ranged from 3.64 to 4.69 across the sites with no obvious wet season/dry season differences.

Chlorophyll $a$ concentrations were highly variable between sampling occasions in the dry season in both years, ranging from 2.25 to $7.41 \mu \mathrm{g} \mathrm{L}^{-1}$ (Fig. 3). The decrease in salinity in the first wet season coincided with a reduction of chlorophyll to below the limit of detection, but concentrations increased gradually to reach $3.94 \mu \mathrm{g} \mathrm{L}^{-1}$ by March. The reduction in salinity in the second wet season also decreased chlorophyll $a$ concentrations but they were more variable. Secchi depths decreased at the start of the wet season in the first year but increased at the start of the wet season in the second year (Fig. 3).

There was little difference in TP and TN concentrations in the transects up the length of the estuary (conducted twice in one dry season, and once in each wet season) between the wet and dry seasons, and between sites upstream and downstream. Chlorophyll $a$ concentrations were only measured in the dry season. On the first sampling occasion there was a peak downstream but on the second occasion concentrations were higher upstream.

The molar DIN:FRP ratios across all sites were less than the Redfield (1958) ratio at the lowest salinities and typically higher when salinities were greater than 2 (Fig. 4).

Salinity was positively and significantly correlated with TSS and chlorophyll $a$ concentrations $\left(\mathrm{R}^{2}=0.480\right.$ and 0.340 respectively), and negatively with FRP when data from both the wet and dry seasons were used $\left(R^{2}=0.452\right.$ respectively, Table 2$)$. TP and TN concentrations were highly and positively correlated $(P<0.001)$ with each other, as was TP and TSS. while secchi depth was negatively correlated with these parameters. However none of these parameters were significantly correlated with chlorophyll $a$ concentrations. In contrast, chlorophyll $a$ concentrations were significantly correlated with FRP concentrations but $\mathrm{R}^{2}$ values were not high (-0.370 
respectively). $\mathrm{NO}_{2}+\mathrm{NO}_{3}$ and FRP also were highly correlated with each other $\left(\mathrm{R}^{2}=\right.$ 0.650). When only data from the dry season was used, chlorophyll $a$ was not correlated with any parameters.

\section{Process studies}

Depth-integrated primary productivity measurements were highest overall in November 2009 (dry season, $1.19-4.04 \mathrm{mmol} \mathrm{C} \mathrm{m}^{-2} \mathrm{~h}^{-1}$ ), when chlorophyll $a$ concentrations were highest, and lowest in January $2009\left(0.14-0.33 \mathrm{mmol} \mathrm{C} \mathrm{m}^{-2} \mathrm{~h}^{-1}\right)$ (Table 3). In the second wet season (February 2010), values were intermediate. Across the three sampling occasions, primary productivity rates were poorly correlated with chlorophyll $a$ concentrations $\left(\mathrm{R}^{2}=0.32\right)$. However, within each sampling trip, the correlation improved, i.e. $\mathrm{R}^{2}=0.86,0.40$ and 0.99 in January 2009, November 2009 and February 2010 respectively. The slope of the line of best fit also changed substantially between sampling occasions $(y=11.1 \mathrm{x}-39.4, \mathrm{y}=42.4 \mathrm{x}+18.6$ and $y=17.4 x+146.9$ in January 2009, November 2009 and February 2010 respectively). Regressing the composite variable $\mathrm{B} \times \mathrm{Z}$ x I, the product of chlorophyll $a$ concentrations, euphotic depth and surface irradiance with primary productivity at each site and sampling occasion resulted in $\mathrm{R}^{2}=0.68$.

$\mathrm{N}$ uptake rates were also highest in November 2009 (Table 3). $\mathrm{NH}_{4}$ uptake rates were highest, followed by urea, and then $\mathrm{NO}_{3}$, with the exception of January 2009 when urea uptake rates were highest. Turnover times for all forms of $\mathrm{N}$ were less than an hour in the dry season, 2 to $13 \mathrm{~h}$ in the second wet season, and 5 to $71 \mathrm{~h}$ in the first wet season.

The photosynthetic yield of phytoplankton increased with the addition of $\mathrm{N}$, and $\mathrm{N}+\mathrm{P}$ at all three sites in both the dry season (November 2009) and the second wet season (February 2010) (Fig. 5). There was no positive response to $\mathrm{P}$ with the exception of one site in February 2010. In the first wet season, there was no response to $\mathrm{N}$ or $\mathrm{N}+\mathrm{P}$ additions at three of the four sites.

The relationship between turbidity and water speed near the mouth of the Norman River estuary was examined over three days in the dry season (November 2009) (Fig. 
6). Turbidity tended to be highest an hour or two after the maximum ebbing flow, with a lesser increase during the flooding tide.

\section{$N$ and $P$ budget}

There was a net flux of DIN out of the estuary on most sampling occasions during both dry seasons, although there was limited data for the first year (Fig. 7a). On only one occasion was there a net flux into the estuary. In the case of FRP, there was more often a net flux out of the estuary than into the estuary (Fig. 7b).

Using the longitudinal DIN data from November 2009 (Fig. 7a), the integrated DIN concentration along the length of the estuary (CQ3 to mouth) yielded a mass of $12.6 \mathrm{t}$ of $\mathrm{N}$ on 4 November 2009 which decreased to 4.9 t on the 28 November 2009. The calculated rate of loss of $\mathrm{N}$ over the 20 days was thus $0.32 \mathrm{t} \mathrm{d}^{-1}$. The calculated DIN uptake rates by phytoplankton across the length of the estuary (CQ3 to mouth) ranged from 0.36 to $3.36 \mathrm{t} \mathrm{d}^{-1}$ on 4 November, to 0.99 to $7.68 \mathrm{t} \mathrm{d}^{-1}$ on 20 November 2009. For FRP, the masses of $\mathrm{P}$ at the beginning and end of the period are 1.33 and $0.93 \mathrm{t}$ respectively implying a loss rate of $0.02 \mathrm{t} \mathrm{d}^{-1}$ (Fig. 7b). For particulate $\mathrm{N}(\mathrm{PN})$ and $\mathrm{P}$, the effluxes averaged over the three days of available measurements in the dry season were $0.89 \pm 0.18 \mathrm{t} \mathrm{d}^{-1}$ and $0.17 \mathrm{t} \mathrm{d}^{-1}$ respectively.

The wet season in 2009 resulted in a total of $4300 \mathrm{~T} \mathrm{~N}$ and $800 \mathrm{~T} \mathrm{P}$ exported from the estuary, while in 2010, $2500 \mathrm{t} \mathrm{N}$ and $400 \mathrm{t} \mathrm{P}$ were exported. These differences were principally due to the higher total volume of water leaving the estuary in the first year compared with the second year.

\section{Discussion}

Our study showed that wet season freshwater flows resulted in a decrease in phytoplankton biomass and ${ }^{13} \mathrm{C}$-uptake, as a measure of primary productivity, compared with the dry season in a tropical dryland estuary. The duration and magnitude of the freshwater flow affected the scale of the impact on phytoplankton. Pradeep Ram et al. (2003) also found lower primary productivity in the Mandovi and Zuari River estuaries, India in the wet compared with the dry season. Additionally, Sarma et al. (2009), in a study of the Godavari River estuary, India, found that 
chlorophyll $a$ concentrations decreased with increasing discharge rates, but no significant relationship was found between primary productivity and discharge rates, due to other confounding factors. The results of the current study are consistent with Eyre's (2000) proposed flood state for subtropical estuaries where freshwater flushes nutrients and sediments out to sea. However, in contrast to Eyre's (2000) post-flood state where during medium flow, increasing light and nutrient availability stimulates phytoplankton biomass, the current study found no evidence of a stimulation of primary productivity as salinity increased following the cessation of freshwater flow.

One explanation for the lack of stimulation of phytoplankton growth post-flow in the current study may be because nutrient concentrations did not increase as salinity increased. There was a variable change in $\mathrm{NH}_{4}$ and FRP was at the start of each wet season, and $\mathrm{NO}_{3}$ did not increase at all. It is more typical for nutrient concentrations to increase as a result of freshwater flow. In part this is because many areas of the world have elevated anthropogenic nutrient concentrations in rivers, estuaries and coasts (Boyer et al., 2006). This may be the result of intensive agriculture, mining, untreated sewage, urban runoff and/or industrialization. Agricultural land, for example, has been shown to leach $\mathrm{NO}_{3}$ and FRP into waterways (Eyre, 1994; Colbert and McManus, 2003; Jennerjahn et al., 2004). Studies have shown that the elevated nutrient loads result in increased algal biomass, and a higher incidence of harmful algal blooms (Beman et al., 2005). Sarma et al. (2009) found that higher nutrient concentrations following a high discharge period increased chlorophyll $a$ concentrations in Godavari River estuary, India. O’Donohue and Dennison (1997) found that phytoplankton productivity peaked in a subtropical estuary after rainfall events.

One reason why there was little evidence of an increase in nutrient concentrations during or post-flow in this study may be because the Norman River catchment is lowlying with little vertical relief resulting in flooding which lasts a number of months, it has soil with low fertility, and the agriculture is low-intensity rangeland grazing (Wilson et al., 2009). Therefore, it is not surprising that catchment inputs of nutrients were low. Indeed, Halpern et al. (2008) found the adjacent marine system, the Gulf of Carpentaria, to be one of the least anthropogenically impacted regions on earth. 
Despite the fact that the nutrient concentrations did not increase during the wet season, a large volume of water did pass through the estuary. This resulted in thousands of tonnes of $\mathrm{N}$ and hundreds of tonnes of $\mathrm{P}$ being exported out the estuary to the nearshore zone. However, there was little evidence of influx of these nutrients back into the estuary in the dry season when tidal exchanges had re-established. This may also explain why there was no post-flood increase in phytoplankton biomass. The coastal waters of the Gulf of Carpentaria are $\mathrm{N}$ depauperate so $\mathrm{N}$ loads from the catchment are likely to have a significant effects on water column and nearshore benthic productivity (Burford et al., 2009). Nutrient loads from the estuary in the current study were comparable with discharges from another tropical dryland river system with an agricultural catchment, the Fitzroy River (Webster et al. 2005).

Downing et al. (1999) found that, globally, tropical rivers had higher $\mathrm{N}$ discharge than temperate systems, and estimated a discharge range of $200-1000 \mathrm{~kg} \mathrm{~N} \mathrm{~km}^{2}$ catchment $\mathrm{y}^{-1}$. The current study is on the low end of this range when wet and dry season $\mathrm{N}$ loads are combined.

Many studies of freshwater flow and estuarine fisheries have found a correlation between catch and the magnitude of freshwater flow (Robins et al., 2005). This has included rivers in the southern Gulf of Carpentaria (Vance et al., 1985). It has been proposed that increased estuarine productivity, as a result of increased nutrient inputs, is one of the mechanisms. However, there was no evidence of significant and sustained increases in nutrient concentrations as a result of freshwater flow, or increased phytoplankton biomass during or after these flow events. Positive effects of increased flow are confined to the mangroves and intertidal mudflats (M. Duggan, pers. comm.). Additionally, the extensive saltflat areas adjacent to the estuary flood each wet season resulting in substantial benthic algal growth (M. Burford, pers. comm.).

Another possible explanation for reduced chlorophyll $a$ concentrations during the wet season may be because higher flow rates reduced water residence time, thereby flushing phytoplankton out of the system. The mean calculated water residence time, based on the estuary volume and flow rate, was approximately $1.4 \mathrm{~d}$ in the 2009 wet season and $2.8 \mathrm{~d}$ in the 2010 wet season. However, a study of tropical Australian phytoplankton found doubling rates ranging from 1 to several doublings $\mathrm{d}^{-1}$ (Furnas et 
al. 2005). These rates are sufficiently high to prevent flushing of phytoplankton over the wet season, although early in the wet season, when flow rates were higher, flushing may have occurred. Although primary productivity rates always increased with increasing chlorophyll $a$ concentrations on the three trips, the relationship between chlorophyll $a$ and primary productivity differed between trips suggesting that the phytoplankton community composition may have changed in response to low salinity.

Phytoplankton productivity in this estuary ranged from $0.31 \pm 0.12$ to $3.44 \pm 1.78$ mmol $\mathrm{C} \mathrm{m}^{-2} \mathrm{~h}^{-1}$ and chlorophyll $a$ concentrations ranged from 0.2 to $8.8 \mu \mathrm{g} \mathrm{L}^{-1}$. The nutrient and chlorophyll $a$ concentrations, and primary productivity rates in this study were comparable with a number of other mangrove estuaries receiving low anthropogenic inputs (Robertson et al., 1993; Burford et al., 2008; Davis et al., 2009; Smith et al., in press). However, surprisingly, a number of studies in tropical estuaries with a higher anthropogenic nutrient load found similar primary productivity rates and chlorophyll $a$ concentrations, for example, a tropical Vietnamese estuary where productivity and chlorophyll $a$ concentrations ranged from 0.5 to $10 \mathrm{mmol} \mathrm{C} \mathrm{m}{ }^{-2} \mathrm{~h}^{-1}$ and 0.8 to $22.9 \mu \mathrm{g} \mathrm{L}^{-1}$ respectively (Rochelle-Newall et al. 2011). Similarly in a tropical Indian estuary with a degraded catchment, productivity and chlorophyll a concentrations were 1.3 to $4.0 \mathrm{mmol} \mathrm{C} \mathrm{m}^{-2} \mathrm{~h}^{-1}$ (assuming $12 \mathrm{~h}$ daylight) and 1.4 to 4.7 $\mu \mathrm{g} \mathrm{L}{ }^{-1}$ respectively (Sarma et al. 2009). The lack of an increased phytoplankton response to anthropogenic nutrient inputs may be because high turbidity in estuaries limit light availability for growth (Cole and Cloern 1987).

Light was likely to be controlling phytoplankton growth in the Norman River estuary. Based on a mean secchi depth of $0.2 \mathrm{~m}$, the calculated average light intensity experienced by a well mixed phytoplankton community was approximately $4 \%$ of surface light. This compares with maximum ${ }^{13} \mathrm{C}$-uptake rates measured in this study at 25 to $100 \%$ of surface light. Therefore the light exposure of the phytoplankton community was typically lower than that required for maximum primary productivity rates. The correlation $\left(\mathrm{R}^{2}=0.68\right)$ between primary productivity and the composite variable, B x Z x I which combines biomass and light measures (Cole and Cloern 1987) across sites and sampling times is consistent with light playing an important 
role in regulating productivity. Additionally, the correlation between primary productivity and algal biomass suggests that physiological processes and species composition are less important in affecting primary productivity rates.

Tidal mixing and sediment resuspension appear to be the major processes affecting turbidity in the estuary. The results suggest that much of the turbidity in the estuary mouth was due to active resuspension rather than simply advection of a turbidity gradient past the site of measurement. Although, in contrast to other studies, the highest turbidity was on the ebbing rather than the flooding tide (Webster and Ford, 2010). This implies that the increase in turbidity is generated within the estuary due to tidal mixing. It is acknowledged that this finding is based on a short term dataset.

This study found substantial internal cycling of nutrients within the estuary to meet nutrient demands of phytoplankton. $\mathrm{N}$ fixation in the water column in the estuary was not an important source of $\mathrm{N}$, as evidenced by the enriched $\delta^{15} \mathrm{~N}$ values (Fry 2006). Therefore new sources of $\mathrm{N}$ are more likely to come from $\mathrm{N}$ fixation on the mudflats or mangrove forests (Boto and Robertson, 1990; Dittmar and Lara, 2001). Studies have found that biological processes such as $\mathrm{N}$ fixation dominate in the subtropics and tropics compared with temperate systems (Bianchi, 2007). Using areal rates of $\mathrm{N}$ fixation in mangrove forests in Boto and Robertson's (1990) study, multiplied by the areas of mangrove and mudflat in the Norman River system, this study estimated that $0.15 \mathrm{t} \mathrm{N} \mathrm{d}^{-1}$ could be added from $\mathrm{N}$ fixation during the dry season. This is not a significant amount of new $\mathrm{N}$ when compared with rates of $\mathrm{N}$ uptake by phytoplankton in the range of 0.36 to $7.68 \mathrm{t} \mathrm{N} \mathrm{d}^{-1}$. It is also not significant compared with the $1.3 \mathrm{t} \mathrm{N}$ $\mathrm{d}^{-1}$ DIN and $0.9 \mathrm{t} \mathrm{N} \mathrm{d}^{-1} \mathrm{PN}$ exported from the estuary on outgoing tides. Based on these estimates, there is a net loss of $\mathrm{N}$ from the estuary in the dry season, even without accounting for denitrification which can exceed $\mathrm{N}$ fixation in estuarine systems (Bianchi, 2007). It has already been demonstrated that total $\mathrm{N}$ concentrations did not increase in the estuary during the wet season. However, substantial sediment deposition was observed on the intertidal mudflats during the wet season. Post-wet season, as salinity levels increased, microphytobenthic biomass concentrations exceeded values prior to the wet season (M. Duggan, pers. comm.). This suggests that 
nutrients deposited with sediment may be stimulating productivity on the intertidal mudflats. This may have flow-on effects to phytoplankton via $\mathrm{N}$ remineralization processes in the sediment (Eyre and Ferguson, 2006). Boynton and Kemp (1985) found 13 to $40 \%$ of $\mathrm{N}$ requirements by algae in an estuary supported by $\mathrm{NH}_{4}$ effluxes. There was little evidence for new nutrient inputs from tidal pulsing in this study.

Consistent with the high measured $\mathrm{N}$ turnover, addition of DIN resulted in increased photosynthetic activity in algal bioassays suggesting that $\mathrm{N}$ is a key limiting nutrient. Process studies are likely to give a more realistic assessment of nutrient limitation than correlations between water quality parameters, or Redfield (1958) ratios (Håkanson and Stenström-Khalili, 2009). The N response in the algal bioassays, and rapid turnover of $\mathrm{N}$ is typical of many estuarine systems. Other studies in Australian estuaries have found similar results (Harris, 2001; Burford et al., 2008; Burford et al., 2011; Smith et al., in press). Additionally, other studies have found that utilization of organic forms of $\mathrm{N}$, i.e. urea, as well as inorganic forms by phytoplankton, is important (Twomey et al., 2005; Torres-Valdes and Purdie, 2006; Burford et al., 2011). DON utilization is often not considered in studies of $\mathrm{N}$ demand by phytoplankton. However, in this study, DON was the dominant form of N, consistent with a less anthropogenically disturbed catchment (Harris, 2001). One component of this, urea, was a significant contributor to phytoplankton $\mathrm{N}$ requirements.

Future development of agricultural land in the southern Gulf of Carpentaria is likely with the increased demand for food production in Australia (CSIRO, 2009). This will lead to intensification of agriculture, including irrigated agriculture, and is likely to increase sediment and nutrient loads to waterways. A key question is whether the increased nutrient loads will result in an increase in estuarine productivity, during or post-wet season, as described by Eyre (2000) for estuaries impacted by agricultural development. Although the estuary is $\mathrm{N}$ depauperate, the high turbidity of the estuary is likely to limit the phytoplankton response most of the time. It may be only during periods of low tidal movement and low wind mixing, resulting in decreased light attenuation, that phytoplankton biomass may temporary increase in response to increased nutrient availability. 
Many of the attributes of the seasonal phases for subtropical estuaries proposed by Eyre (2000) are consistent with this study. However, there were some key differences. Firstly, there was little evidence of remineralized nutrients from high flow conditions increasing phytoplankton biomass in the Norman River estuary. This may be, in part, because there was little increase in nutrient concentrations during the flow events. Additionally there was no evidence of substantial nutrient loads returning from coastal waters via tidal pulsing during the dry season. The estuary was turbid throughout the year, irrespective of the flow regimes, and phytoplankton were likely to be perpetually light limited. A key difference between this system and those in the study of Eyre (2000) was that this system was not heavily impacted by agriculture, and soils were of low fertility.

In summary, this study found that major freshwater inputs to a tropical dryland estuary resulted in a reduction in phytoplankton biomass and productivity, with the duration of flow, and associated low salinity, affecting the magnitude of the biomass and productivity response. In contrast with many other studies, freshwater did not have major effects on nutrient concentrations or light availability for phytoplankton growth in the estuary. Overall, light availability is to be a key limiting factor for phytoplankton production which may limit the effect of future increases in nutrient loads on phytoplankton growth. 


\section{Acknowledgements}

We wish to thank Geoff Moore for assistance with regular field sampling, Dominic Valdez, Stephen Faggotter and Melissa Duggan for assistance with intensive field trips, management and staff at Raptis and Sons for allowing us access to their facilities and regular advice and assistance, Rene Diocares for analysis of stable isotope samples, and Queensland Health for analysis of nutrient and alkalinity samples.

This project was conducted as part of the Tropical Rivers and Coastal Knowledge (TRaCK) program. TRaCK receives major funding for its research through the Australian Government's Commonwealth Environment Research Facilities initiative; the Australian Government's Raising National Water Standards Program; Land and Water Australia; the Fisheries Research and Development Corporation and the Queensland Government's Smart State Innovation Fund. 


\section{References}

American Public Health Association (APHA), 2005. Standard Methods for the Examination of Water and Wastewater. 21st Edn. Greenburg, A.E., Clesceri, L.S., Eaton, A.D. (Eds.) American Public Health Association, Washington, D.C.

Beman, J.M., Arrigo, K.R., Matson, P.A., 2005. Agricultural runoff fuels large phytoplankton blooms in vulnerable areas of the ocean. Nature 434, 211-214.

Bianchi, T.S., 2007. Biogeochemistry of Estuaries. Oxford University Press: Oxford.706 pp.

Boto, K.G., Robertson A.I., 1990. The relationship between $\mathrm{N}$ fixation and tidal exports of $\mathrm{N}$ in a tropical mangrove system. Estuarine, Coastal and Shelf Science 31, 531-540.

Boyer, E.W.; Howarth, R.W.; Galloway, J.N.; Dentener, F.J.; Green, P.A.; Vorosmarty, C.J. 2006. Riverine nitrogen export from the continents to the coasts. Global Biogeochemical Cycles 20, GB1S91, doi:10.1029/2005GB002537

Boynton, W.R., Kemp, W.R., 1985. Nutrient regeneration and oxygen consumption by sediments along an estuarine gradient. Marine Ecology Progress Series 23, 45-55.

Bucher, D., Saenger, P., 1994. A classification of tropical and subtropical Australian estuaries. Aquatic Conservation: Marine and Freshwater Ecosystems 4, 1-19.

Burford, M.A., Alongi, D.M., McKinnon, A.D., Trott, L.J., 2008. Primary production and nutrients in a tropical macrotidal estuary, Darwin Harbour, Australia. Estuarine, Coastal and Shelf Science, 79, 440-448.

Burford, M.A., Rothlisberg, P.C., Revill, A. T., 2009. Sources of nutrients driving production in the Gulf of Carpentaria, Australia - a shallow tropical shelf system. Marine and Freshwater Research 60, 1044-1053.

Burford, M. A., Revill, A.T. Palmer, D.W. Clementson, L., Robson, B.J., Webster, I.T., 2011. River regulation alters drivers of primary productivity along a tropical river-estuary system. Marine and Freshwater Research 62, 141-151. 
Chapra, S.C., 1997. Surface Water-Quality Modeling. WCB/McGraw-Hill, New York, $844 \mathrm{pp}$.

Colbert, D., McManus, J., 2003. Nutrient biogeochemistry in an upwelling-influenced estuary of the Pacific northwest (Tillamook Bay, Oregon, USA). Estuaries 26, 1205-1219.

Cole, B.E., Cloern, J.E. 1987. An empirical model for estimating phytoplankton productivity in estuaries. Marine Ecology Progress Series 36, 299-305.

CSIRO 2009. Northern Australia Land and Water Science Review 2009. CSIRO, Australia

Davis, S.E., Lirman, D., Wozniak, J.R., 2009. N and P exchange among tropical coastal systems. In: Nagelkerken I. (Ed.) Ecological Connectivity among Tropical Coastal Ecosystems. Spring Dordrecht, Heidelberg, pp. 9 - 44.

Dittmar, T., Lara, R.J., 2001. Driving forces behind nutrient and organic matter dynamics in a mangrove tidal creek in north Brazil. Estuarine, Coastal and Shelf Science 52, 249-259.

Downing, J.A., McClain, M., Twilley, R., Melack, J.M., Elser, J., Rabalais, N.N., Lewis, W.M., Turner, R.E., Corredor, J., Soto, D., Yanez-Arancibia, A., Kospaska, J.A., Howarth, R.W., 1999. The impact of accelerating land-use change on the $\mathrm{N}$-cycle of tropical aquatic ecosystems: Current conditions and projected changes. Biogeochemistry 46, 109-148.

Dugdale, R.C., Goering, J.J., 1967. Uptake of new regenerated forms of N in primary productivity. Limnology and Oceanography 12, 196-206.

Eyre, B., 1994. Nutrient biogeochemistry in the tropical Moresby River estuary system, north Queensland, Australia. Estuarine, Coastal and Shelf Science 39, 15-31.

Eyre, B.D., 2000. A regional evaluation of the nutrient transformation and phytoplankton growth in nine river dominated sub-tropical East Australian estuaries. Marine Ecology Progress Series 205, 61-83.

Eyre, B.D., Ferguson, A.J.P., 2006. Impact of a flood event on benthic and pelagic coupling in a sub-tropical east Australian estuary (Brunswick). Estuarine, Coastal and Shelf Science 66, 111-122.

Furnas, M., Mitchell, A., Skuza, M., Brodie, J. 2005. In the other 90\%: phytoplankton responses to enhanced nutrient availability in the Great Barrier Reef Lagoon. Marine Pollution Bulletin 51, 253-265. 
Fry, B., 2006. Stable Isotope Ecology. Springer, New York.

Ganf G.G., Rea N., 2007. Potential for algal blooms in tropical rivers of the Northern Territory, Australia. Marine and Freshwater Research 58, 315-326.

Gillanders B.M., Kingsford M. J., 2002. Impact of changes in flow of freshwater on estuarine and open coastal habitats and the associated organisms. Oceanography and Marine Biology: an Annual Review 40, 233-309.

Glibert, P.M., Garside, C., Fuhrman, J.A., Roman, M.R., 1991. Time-dependent coupling of inorganic and organic $\mathrm{N}$ uptake and regeneration in the plume of the Chesapeake Bay estuary and its regulation by large heterotrophs. Limnology and Oceanography 36, 895-909.

Håkanson, L., Stenström-Khalili, M.I., 2009. Uncertainties in data and spurious correlations related to the Redfield ratio. International Review of Hydrobiology 94, 338-351.

Halpern, B.S., Walbridge, S., Selkoe, K.A., Kappel, C.V., Micheli, F., et al., 2008. A global map of human impact on marine ecosystems. Science 319, 948-952.

Harris, G.P., 2001. Biogeochemistry of N and P in Australian catchments, rivers and estuaries: effects of land use and flow regulation and comparisons with global patterns. Marine and Freshwater Research 52, 139-149.

Jeffrey S.W., Welshmeyer N.A., 1997. Spectrophotometric and fluorometric equations in common use in oceanography. In: Jeffrey, S.W., Mantoura, R.F.C., Wright, S.W. (Eds.). Phytoplankton Pigments in Oceanography (Monographs on Oceanographic Methodology No.10. UNESCO Publication, pp. 597-615.

Jennerjahn, T.C., Ittekkot, V., Klopper, S., Adi, S., Purwo Nugroho, S., Sudiana, N., Yusmal, A., Prihartanto, Gaye-Haake, B. 2004. Biogeochemistry of a tropical river affected by human activities in its catchment: Brantas River estuary and coastal waters of Madura Strait, Java, Indonesia. Estuarine, Coastal and Shelf Science 60, 503-514.

Kennard M.J., Pusey B.J., Olden J.D., Mackay S.J., Stein J.L., Marsh N., 2010. Classification of natural flow regimes in Australia to support environmental flow management. Freshwater Biology 55, 171-193.

Kenyon, R.A., Loneragan, N.R., Manson, F.J., Vance, D.J., Venables, W.N., 2004. Allopatric distribution of juvenile red-legged banana prawns (Penaeus indicus 
H. Milne Edwards, 1837) and juvenile white banana prawns (Penaeus merguiensis De Man, 1888), and inferred extensive migration, in the Joseph Bonaparte Gulf, northwest Australia. Journal of experimental Marine Biology and Ecology 309, 79-108

Mallin, M.A., Paerl, H.W., Rudek, J., Bates, P.W., 1993. Regulation of estuarine primary production by watershed rainfall and river flow. Marine Ecology Progress Series 93, 199-203

Murrell, M.C., Hagy, J.D., Lores, E.M., Greene, R.M., 2007. Phytoplankton production and nutrient distributions in a subtropical estuary: Importance of freshwater flow. Estuaries and Coasts 30, 390-402.

O’Donohue, M.J.H., Dennison, W.C. 1997. Phytoplankton productivity response to nutrient concentrations, light availability and temperature along an Australian estuarine gradient. Estuaries 20, 521-533.

Pradeep Ram, A.S., Nair, S., Chandramohan, D., 2003. Season shift in net ecosystem production in a tropical estuary. Limnology and Oceanography 48, 1601-1607.

Rahmatullah, M., Boyde, T.R.C., 1980. Improvements in the determination of urea using diacetyl monoxime; methods with and without deproteinisation. Clinica Chimica Acta 107, 3-9.

Redfield A.C., 1958. The biological control of chemical factors in the environment. American Science 46, 205-222.

Robertson, A.I., Daniel, P.A., Dixon, P., Alongi, D.M., 1993. Pelagic biological processes along a salinity gradient in the Fly delta and adjacent river plume (Papua New Guinea). Continental Shelf Science 13, 205-224.

Robins J.B., Halliday I.A., Staunton-Smith J., Mayer D.G., Sellin M.J., 2005. Freshwater-flow requirements of estuarine fisheries in tropical Australia: a review of the state of knowledge and application of a suggested approach. Marine and Freshwater Research 56, 343-360.

Rochelle-Newall, E.J., Chu, V.T., Pringault, P., Amouroux, D., Arfi, R., Bettarel, Y., Bouvier, T., Bouvier, C., Got, P., Nguyen, T.M.H., Mari, X., Navarro, P., Duong, T.N., Cao, T.T.T., Pham, T.T., Ouillon, S., Torréton, J-P. 2011. Phytoplankton distribution and productivity in a turbid, tropical coastal system (Bach Dang Estuary, Vietnam). Marine Pollution Bulletin 62, 2317-2329. Sarma V.V.S.S., Gupta S.N.M., Babu P.V.R., Acharya T., Harikrishnachari N., Vishnuvardhan K., Rao N.S., Reddy N.P.C., Sharma V.V., Sadhuram Y., Murty 
T.V.R., Kumar M.D., 2009. Influence of river discharge on plankton metabolic rates in the tropical monsoon driven Godavari estuary, India. Estuarine, Coastal and Shelf Science 85, 515-524.

Smith, J., Burford, M.A., Revill, A.T., Haese, R.R., Fortune, J., 201... Effect of nutrient loading on biogeochemical processes in tropical tidal creeks.

Biogeochemistry, in press.

Strickland, J.D.H., 1965. Production of organic matter in the primary stages of the marine food chain. In: Riley, J.P., Skirrow, G. (Eds.) Chemical Oceanography Vol. 1. New York, Academic Press. pp. 477-610.

Torres-Valdes, S., Purdie, D.A., 2006. Nitrogen removal by phytoplankton uptake through a temperate non-turbid estuary. Estuarine, Coastal and Shelf Science 70, 473-486.

Twomey, L.J., Piehler, M.F., Paerl, H.W., 2005. Phytoplankton uptake of ammonium, nitrate and urea in the Neuse River estuary, NC, USA. Hydrobiologia 533, 123 134.

Vance, D.J., Staples, D.J., Kerr, J.D., 1985. Factors affecting year-to-year variation in the catch of banana prawns (Penaeus merguiensis) in the Gulf of Carpentaria, Australia. Journal du Conseil 42, 83-97.

Webster, I.T., Ford, P.W., Tillman, P., 2005. Estimating nutrient budgets in tropical estuaries subject to episodic flows. Marine Pollution Bulletin 51, 165-173.

Webster, I.T., 2010. The hydrodynamics and salinity regime of a coastal lagoon - The Coorong, Australia - Seasonal to multi-decadal timescales. Estuarine, Coastal and Shelf Science 90, 264-274.

Webster, I.T., Ford, P.W., 2010. Delivery, deposition and redistribution of fine sediments within macrotidal Fitzroy Estuary/Keppel Bay: Southern Great Barrier Reef, Australia. Continental Shelf Research 30, 793-805.

Wilson, P.L., Ringrose-Voase, A., Jacquier, D., Gregory, L., Webb, M. et al., 2009. Land and water resources. In: Northern Australia Land and Water Science Review 2009, CSIRO, Australia. 


\section{Figure legend}

Figure 1: Map of sampling area in the Norman River estuary, Queensland, Australia showing regular water quality sampling sites (CQ1, CQ2, CQ3, RQ1, WQ1, NW). CQ1 = incoming tide, $\mathrm{CQ} 2$ = outgoing tide.

Figure 2: a) Hydrograph $\left(\mathrm{m}^{3} \mathrm{~s}^{-1}\right)$ for Norman River, Australia from 1975 to 2010, and b) from the commencement of the study in October 2008 to the completion in June 2010, based on data from a gauging station at the Glenore Weir (www.derm.qld.gov.au).

Figure 3: Mean $( \pm \mathrm{SD})$ salinity, chlorophyll $a$ concentrations $\left(\mu \mathrm{g} \mathrm{L} \mathrm{L}^{-1} \mathrm{chl}\right.$ a), secchi depth (m), $\mathrm{NH}_{4}, \mathrm{NO}_{2}+\mathrm{NO}_{3}$ and FRP $\left(\mu \mathrm{mol} \mathrm{L}{ }^{-1}\right)$ and across sites on the Norman $\mathrm{R}$ estuary from October 2008 to June 2010. Dashed line shows commencement of freshwater flow.

Figure 4: Molar DIN:FRP ratios with increasing salinities across all sites and sampling occasions in the Norman River estuary. Dashed line shows Redfield (1958) ratio.

Figure 5: Photosynthetic yield responses of phytoplankton to nutrients $(\mathrm{N}, \mathrm{P}, \mathrm{N}+\mathrm{P})$ in the water column in the wet (January 2009, February 2010) and dry seasons (November 2009). $* P<0.05$, $* * P<0.01, * * * P<0.005$.

Figure 6: Water speed $\left(\mathrm{m} \mathrm{s}^{-1}\right)$ and turbidity (NTU) measured over $3 \mathrm{~d}$ (Nov/Dec 2009) in the dry season near the mouth of the Norman River estuary. 'High' and 'Low' denotes high and low tides.

Figure 7: Calculated flux of (a) DIN and (b) FRP ( $\left.\mathrm{t} \mathrm{d}^{-1}\right)$ past Site CQ1/2 in the two years of the study, and longitudinal flux based on November 2009 sampling. Negative values are fluxes to the sea. 
Table 1: Mean ( \pm SD) of physico-chemical profile, nutrient, TSS and chlorophyll $a$ data for all sites from the upper to lower estuary across the two years of the study. Data for NW was only collected on the second year. CQ1 is incoming tide, CQ2 is outgoing tide at same site.

\begin{tabular}{|c|c|c|c|c|c|c|}
\hline Parameter & NW & CQ3 & WQ1 & RQ1 & CQ2 & CQ1 \\
\hline $\operatorname{Temp}\left({ }^{\circ} \mathrm{C}\right)$ & $28.9(3.7)$ & $29.3(2.2)$ & $29.3(2.1)$ & $28.3(1.9)$ & $29.5(2.7)$ & $29.5(3.0)$ \\
\hline pH & $7.62(0.37)$ & $7.46(0.44)$ & $7.58(0.45)$ & $7.86(0.36)$ & $7.72(0.38)$ & $7.76(0.57)$ \\
\hline DO $\left(\mathrm{mg} \mathrm{L}^{-1}\right)$ & $6.69(2.82)$ & $5.40(1.25)$ & $5.32(1.37)$ & $5.37(1.35)$ & $5.32(1.05)$ & $5.30(1.38)$ \\
\hline Secchi (m) & $0.40(0.24)$ & $0.17(0.06)$ & $0.22(0.12)$ & $0.19(0.15)$ & $0.24(0.23)$ & $0.38(0.54)$ \\
\hline $\mathbf{T N}\left(\mu \mathrm{mol} \mathrm{L^{-1 } )}\right.$ & $40.50(12.64)$ & $37.21(10.00)$ & $33.14(7.57)$ & $37.36(12.35)$ & 37.14 (13.57) & 31.07 (13.57) \\
\hline TP $\left(\mu \mathrm{mol} \mathrm{L} \mathbf{L}^{-1}\right)$ & $1.48(0.81)$ & $2.58(0.97)$ & $2.16(0.74)$ & $3.45(2.29)$ & $2.77(1.71)$ & $2.32(1.84)$ \\
\hline $\mathrm{NH}_{4}\left(\mu \mathrm{mol} \mathrm{L}{ }^{-1}\right)$ & $1.57(1.64)$ & $0.86(0.50)$ & $1.28(1.00)$ & $1.78(1.50)$ & $1.43(1.57)$ & $0.93(0.78)$ \\
\hline $\left.\mathrm{NO}_{2}+\mathrm{NO}_{3}(\mu \mathrm{mol} \mathrm{L})^{-1}\right)$ & $3.57(2.57)$ & $4.86(5.36)$ & $4.57(5.71)$ & $3.00(2.57)$ & $3.07(2.86)$ & $1.43(1.43)$ \\
\hline $\operatorname{FRP}\left(\mu \mathrm{mol} \mathrm{L} \mathbf{L}^{-1}\right)$ & $0.22(0.10)$ & $0.29(0.20)$ & $0.29(0.22)$ & $0.48(0.61)$ & $0.22(0.13)$ & $0.19(0.16)$ \\
\hline Chl $a\left(\mu g \mathrm{~L}^{-1}\right)$ & $3.90(1.99)$ & $3.89(3.12)$ & $3.39(2.56)$ & $3.40(2.96)$ & $4.65(3.75)$ & $4.14(3.79)$ \\
\hline TSS $\left(\mathrm{mg} \mathrm{L}^{-1}\right)$ & $144.21(140.00)$ & $274.78(188.60)$ & $263.07(211.73)$ & $361.63(211.49)$ & $430.42(530.46)$ & $349.43(338.14)$ \\
\hline Molar TN:TP & 30.23 & 15.6 & 16.9 & 14.3 & 17.69 & 17.9 \\
\hline$\delta^{15} \mathrm{~N}$ POM & $3.64(1.76)$ & $4.06(2.18)$ & $4.67(2.28)$ & $4.32(2.37)$ & $4.69(2.31)$ & $4.61(2.69)$ \\
\hline
\end{tabular}


Table 2: Correlation matrix $\left(\mathrm{R}^{2}\right)$ for water quality parameters across all data in the Norman $\mathrm{R}$. estuary. Temp $=$ temperature. $* * * P<0.001, \mathrm{n}=78$.

\begin{tabular}{|c|c|c|c|c|c|c|c|c|c|c|}
\hline Parameter & TSS & TN & TP & Chl $a$ & $\mathbf{N H}_{4}$ & FRP & $\mathrm{NO}_{2}+\mathrm{NO}_{3}$ & Secchi & Temp. & Salinity \\
\hline TSS & & 0.347 & $0.689 * * *$ & 0.176 & -0.149 & -0.016 & 0.025 & $-0.540 * * *$ & 0.097 & $0.480 * * * *$ \\
\hline TN & & & $0.723 * * *$ & -0.031 & 0.200 & $0.416 * * *$ & $0.484 * * *$ & $-0.502 * * *$ & $0.396 * * *$ & -0.074 \\
\hline TP & & & & -0.062 & 0.091 & $0.385 * * *$ & 0.287 & $-0.856 * * *$ & -0.221 & -0.022 \\
\hline Chl $a$ & & & & & -0.230 & $\mathbf{- 0 . 3 7 0} * * *$ & -0.152 & -0.180 & 0.291 & $0.340 * * *$ \\
\hline $\mathbf{N H}_{4}$ & & & & & & 0.165 & -0.177 & -0.291 & 0.203 & -0.289 \\
\hline FRP & & & & & & & $\mathbf{0 . 6 5 0} * * *$ & -0.232 & -0.117 & $-0.452 * * *$ \\
\hline $\mathrm{NO}_{2}+\mathrm{NO}_{3}$ & & & & & & & & -0.070 & -0.096 & 0.053 \\
\hline Secchi & & & & & & & & & -0.184 & 0.155 \\
\hline Temp. & & & & & & & & & & 0.174 \\
\hline Salinity & & & & & & & & & & \\
\hline
\end{tabular}


Table 3: Mean (SD) physico-chemical parameters and primary productivity measures across three sites on three intensive sampling occasions in the Norman River estuary. $* \mathrm{~N}$ uptake and related nutrients were only measured at one site. $\mathrm{P}_{\max }=$ maximum rates of primary productivity, Depth-int $=$ depth integrated.

\begin{tabular}{|c|c|c|c|}
\hline Parameter & Jan 2009 & Nov 2009 & Feb 2010 \\
\hline Salinity & 0.06 & 34.03 & 0.07 \\
\hline Temperature $\left({ }^{\circ} \mathrm{C}\right)$ & 31.65 & 29.45 & 31.84 \\
\hline Euphotic depth (m) & 0.2 & 1.1 & 0.5 \\
\hline $\mathrm{NH}_{4} \operatorname{conc}\left(\mu \mathrm{mol} \mathrm{L}^{-1} \mathrm{~N}\right)$ & $1.71(0.64)$ & 0.57 & 0.78 \\
\hline $\mathrm{NO}_{2}+\mathrm{NO}_{3} \operatorname{conc}\left(\mu \mathrm{mol} \mathrm{L}^{-1} \mathrm{~N}\right)$ & $0.57(0.21)$ & 0.57 & 1.07 \\
\hline FRP conc $\left(\mu \mathrm{mol} \mathrm{L}^{-1} \mathbf{P}\right)$ & 0.32 & & 0.35 \\
\hline Urea conc $\left(\mu \mathrm{mol} \mathrm{L^{-1 } N )}\right.$ & $1.07(0.14)$ & 1.36 & 1.14 \\
\hline Chlorophyll $a$ conc $\left(\mu \mathrm{g} \mathrm{L}^{-1}\right)$ & $6.90(1.22)$ & $9.30(3.21)$ & $5.48(2.45)$ \\
\hline 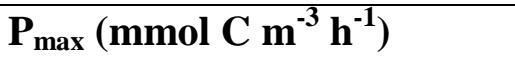 & $2.82(1.64)$ & $6.00(3.14)$ & $6.21(1.28)$ \\
\hline 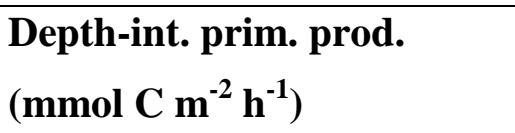 & $0.31(0.12)$ & $3.44(1.78)$ & $2.02(0.35)$ \\
\hline 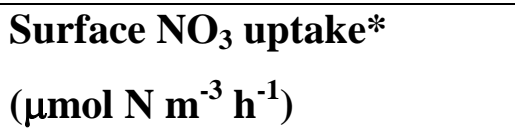 & 11.43 & 872.86 & 60.71 \\
\hline $\begin{array}{l}\text { Surface } \mathrm{NH}_{4} \text { uptake* } \\
\left(\mu \mathrm{mol} \mathbf{N ~ m}^{-3} \mathbf{h}^{-1}\right)\end{array}$ & 100.00 & 1751.43 & 417.86 \\
\hline $\begin{array}{l}\text { Surface urea uptake* } \\
\left(\text { umol } \mathbf{N ~ m}^{-3} h^{-1}\right)\end{array}$ & 176.43 & 1395.71 & 110.00 \\
\hline
\end{tabular}


Figure

1

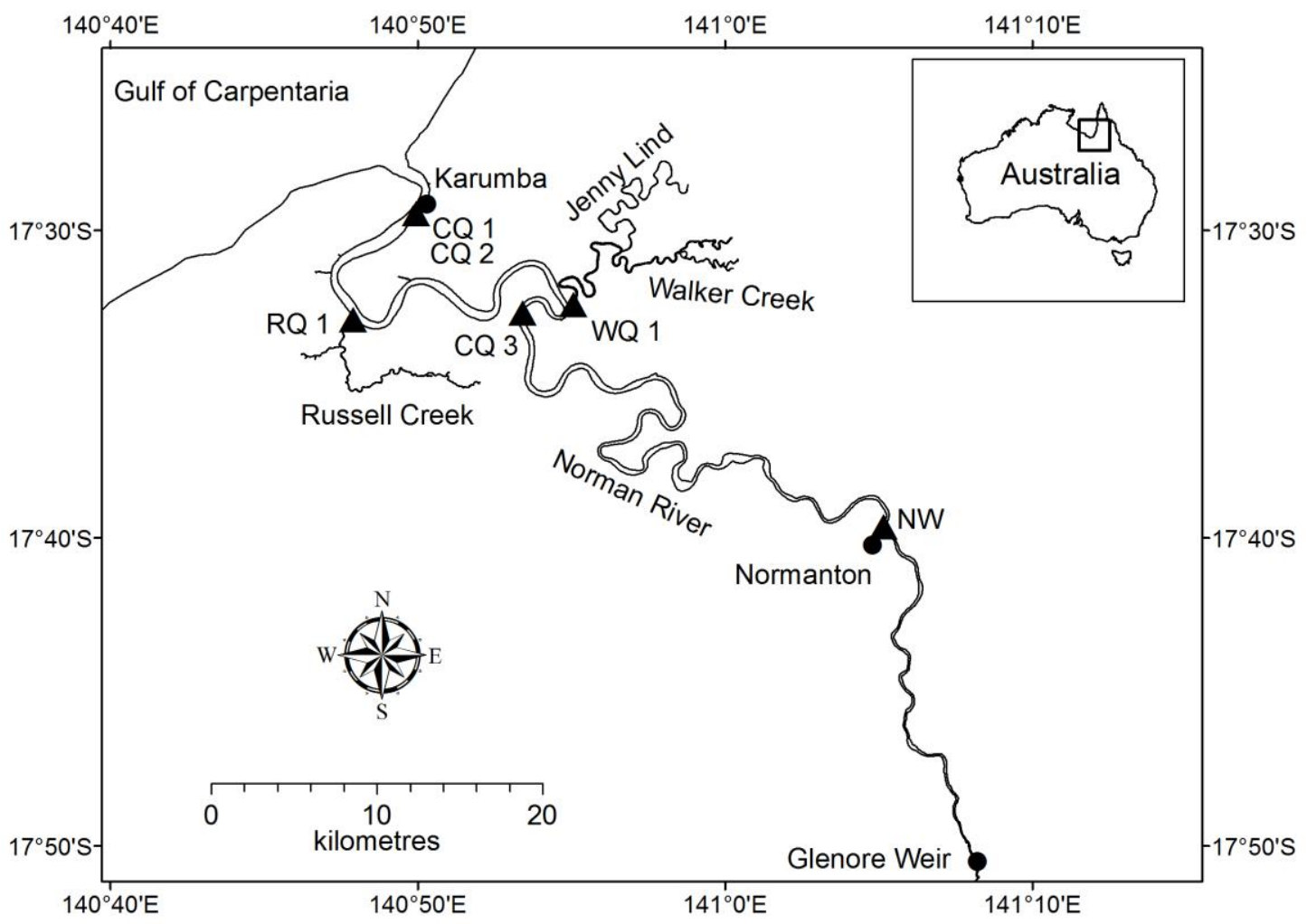


Figure 2

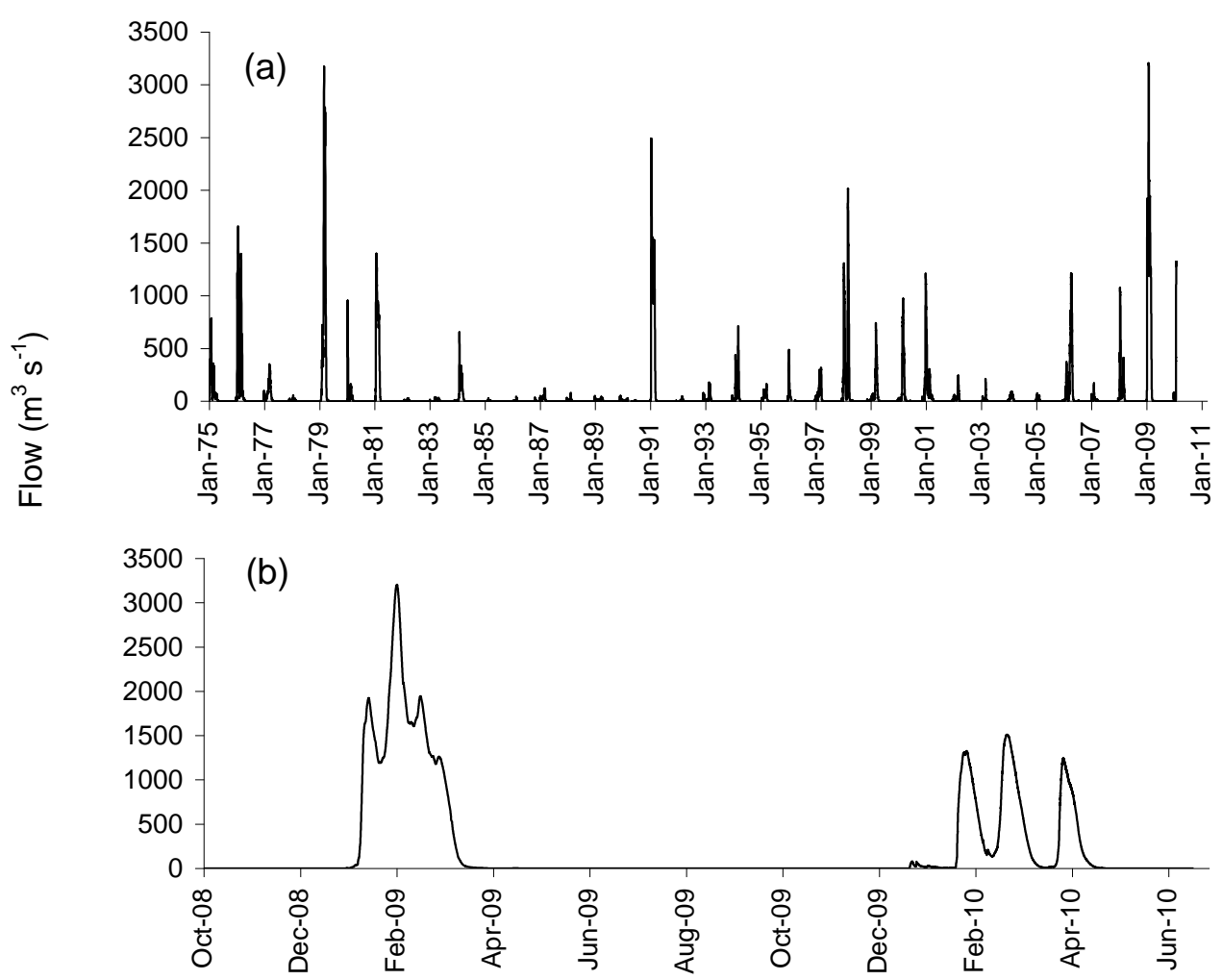


Figure 3
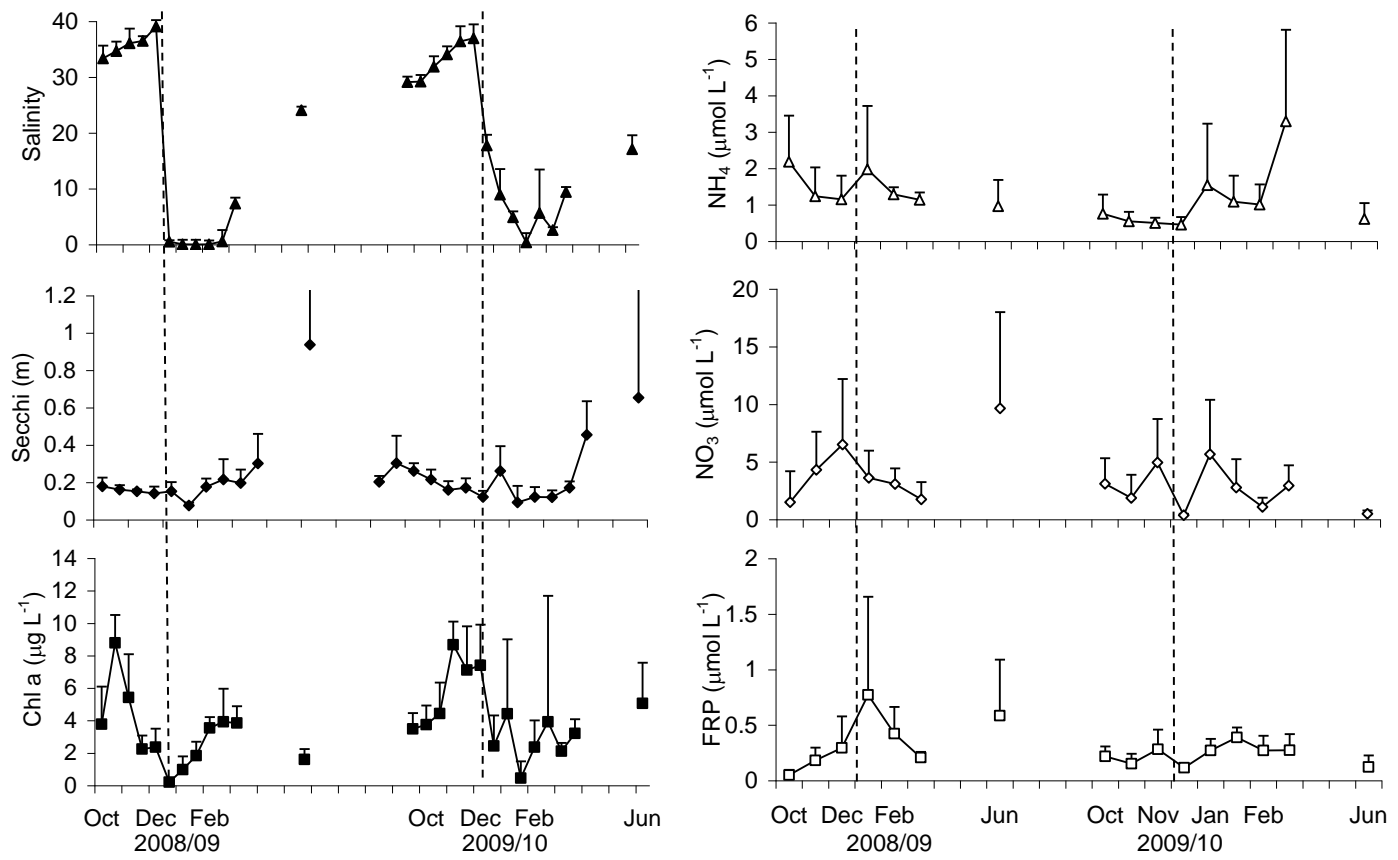
Figure 4

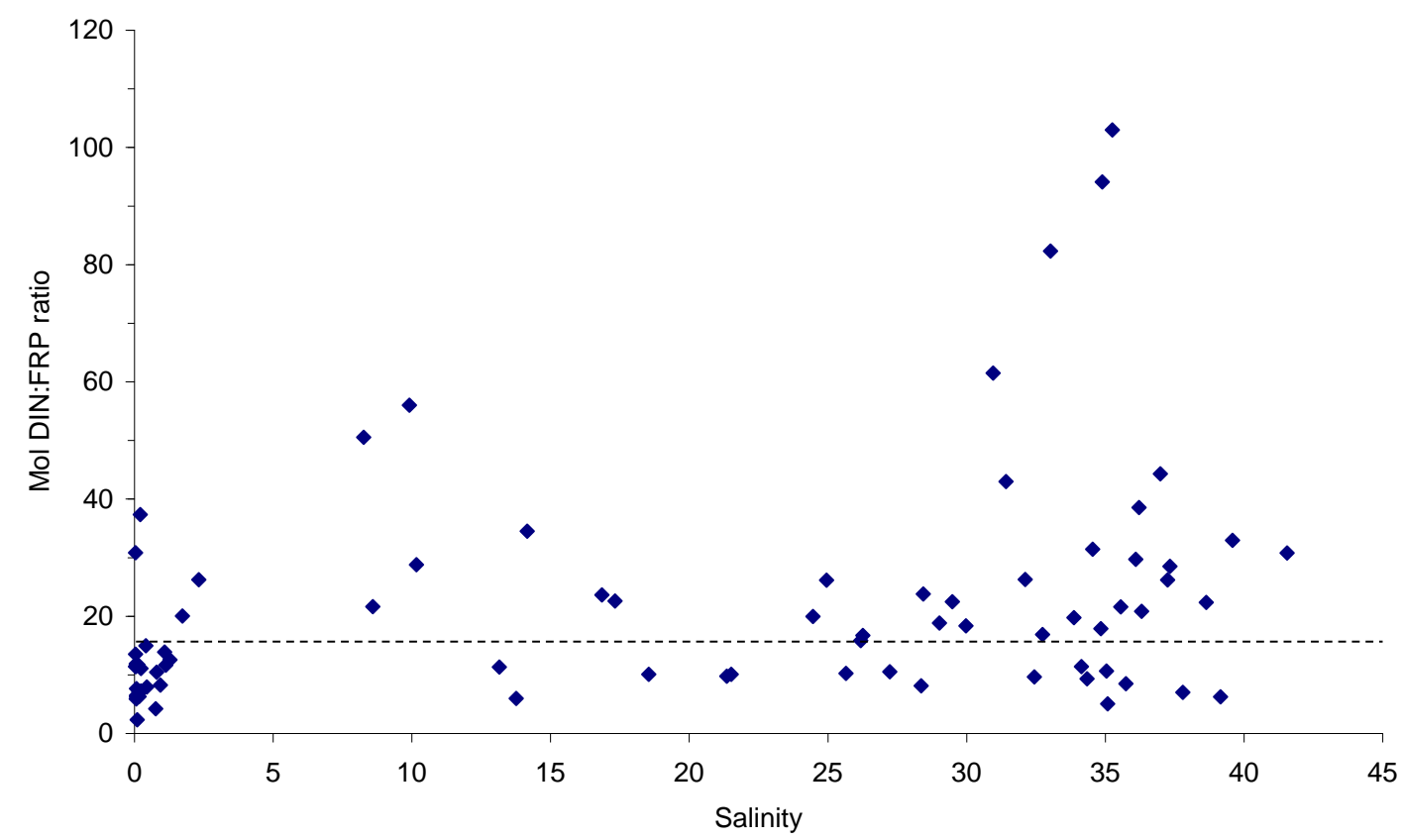


Figure 5

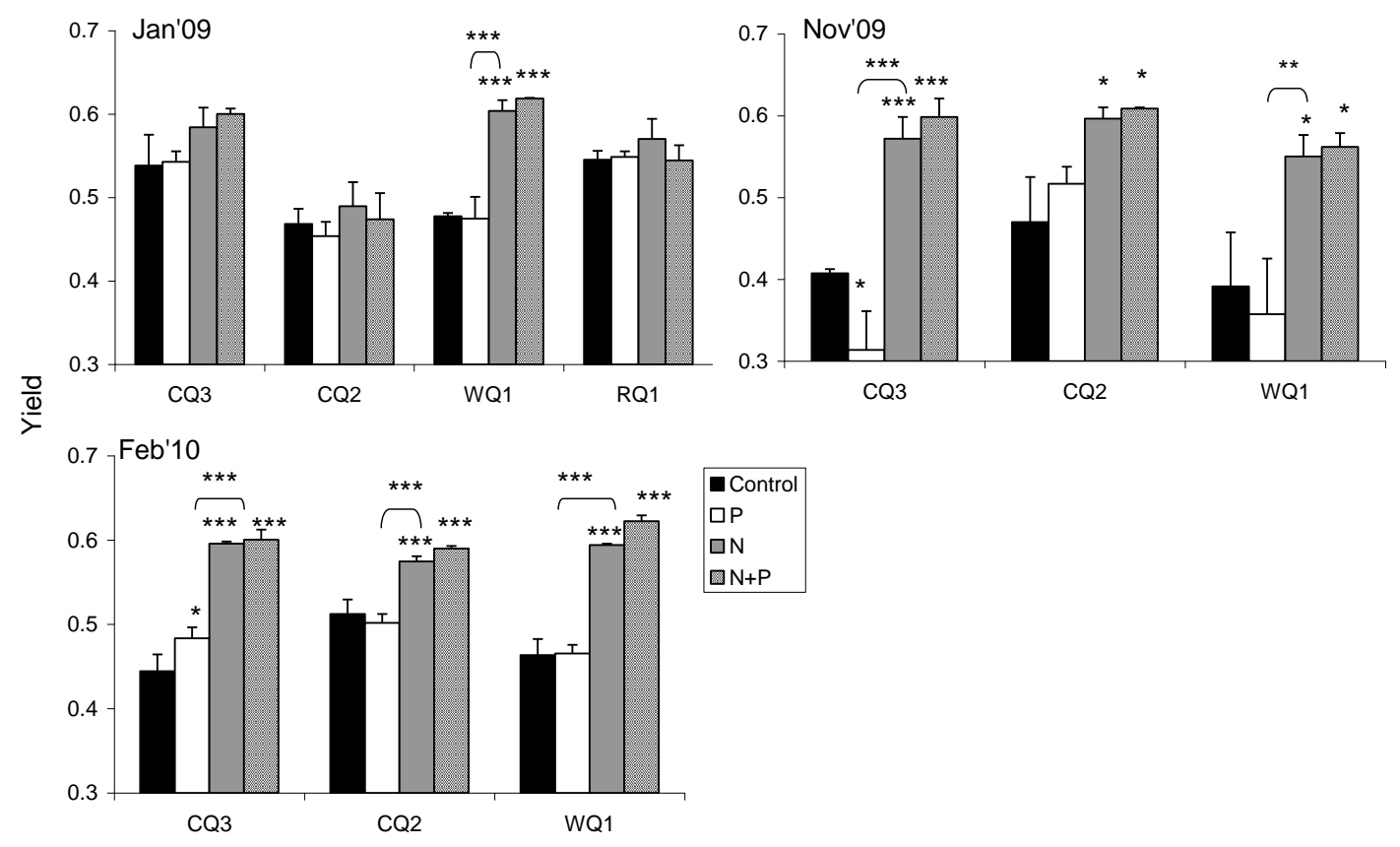


37

Figure 6

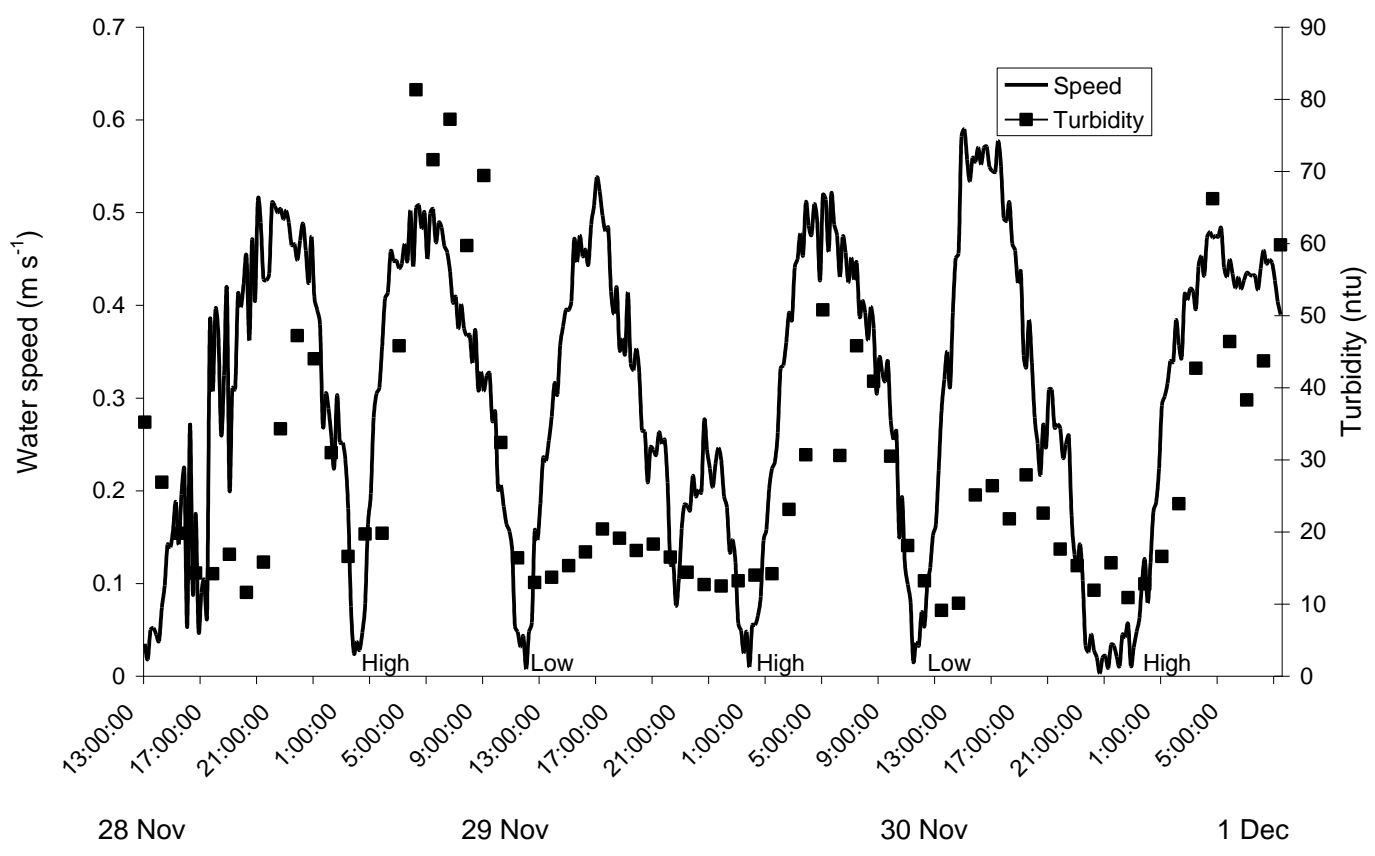


Figure 7
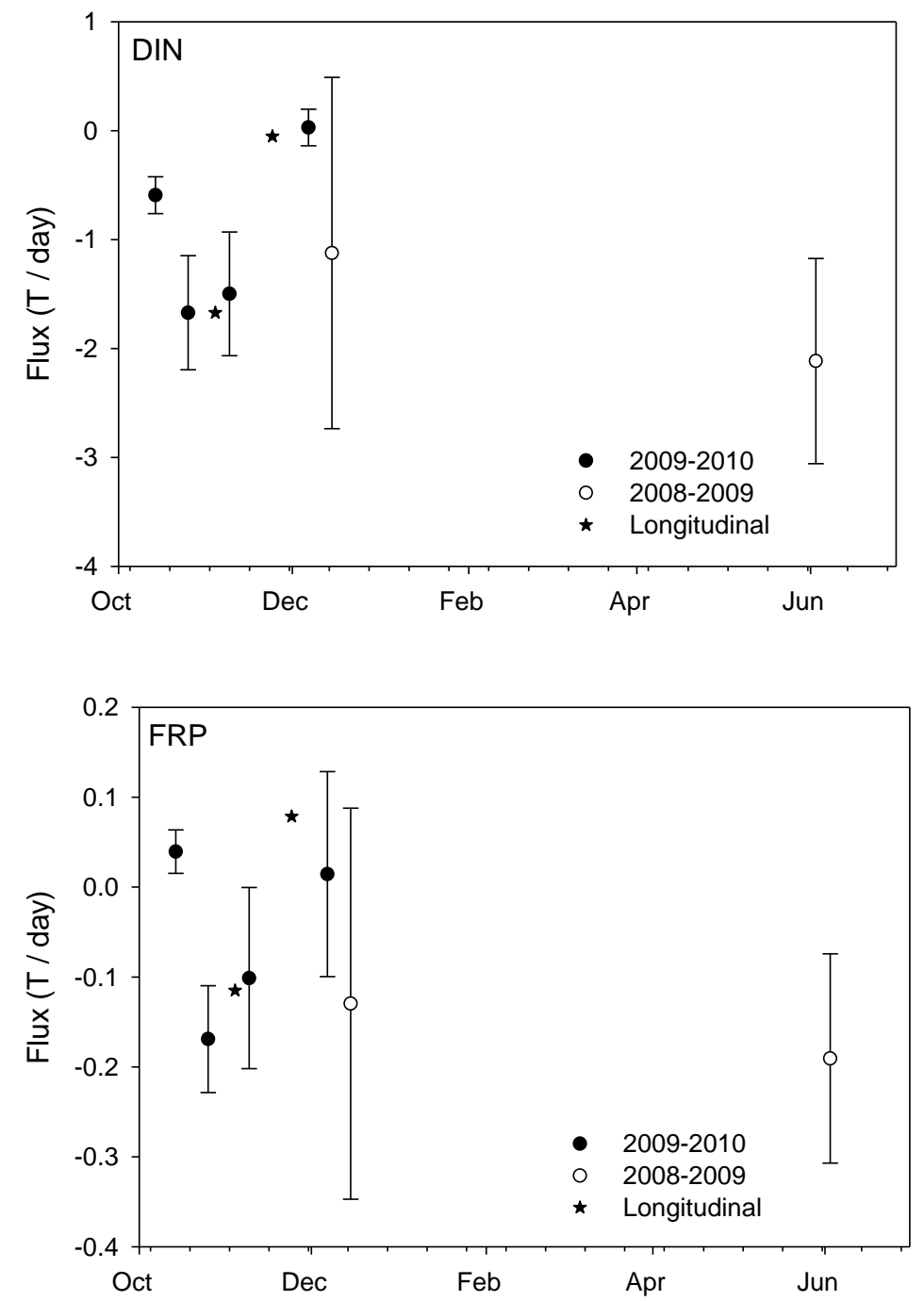